\title{
The Significance of the Constructivist Approach in Preschool Science Education
}

\author{
Janja Plazar \\ University of Primorska \\ janja.plazar@pef.upr.si
}

Science education is of crucial importance to many aspects of a child's development, therefore it is suggested that it should begin already during the early childhood period. Nowadays, science education is based predominantly on the principle of constructivism according to which children act as active participants in the learning process and construct their own knowledge on the basis of experience. This enables them to acquire scientific knowledge and develop the ability to think and solve problems in a logical way. Many authors recommend that it is necessary to start science education in the early preschool period, with competent preschool teachers, who could develop science concepts correctly and maintain positive attitude towards science in children. Alarmingly, many studies agree that science teaching all over the world tends to be deprioritized in early childhood education, compared to teaching literacy, numeracy and arts, mostly due to insufficient science knowledge of the preschool teachers. Therefore, solutions are proposed to provide positive outcomes to preschool science education by increasing both science knowledge and the skills of preschool teachers.

Keywords: preschool science education, constructivism, competent preschool teachers, science concepts, scientific literacy

\section{Introduction}

During the early preschool period, children establish the bases of knowledge and skills which are going to be used throughout their life. Very early in their lives, children start to observe nature and events, seek for answers and questions, and get to understand the primary science related concepts. Hence, there are several good reasons for starting science education already in the preschool period. The teachers working in preschool classrooms have a significant responsibility to develop science concepts correctly and to maintain positive attitudes towards science. Preschool science education should be therefore introduced using appropriate instructional approaches, in which children learn to pay attention, ask questions, observe, analyse, explore and make deductions. One of the most pronounced contemporary science teaching approaches of the last decades is constructivism, according to which chil- 
dren construct their own knowledge as active participants in the learning process on the basis of their own experience.

The aim of the present paper is to expose and emphasize the importance of implemented science education in the early years, and how early science education contributes to scientific literacy and learns scientific concepts to children. As demonstration, a few effective approaches towards teaching science to preschool children will be presented. Additionally, the paper discusses the reasons for the lack of science teaching in preschool classrooms and presents possible solutions to increase the quality of science education in the preschool years.

\section{Exposure to Science in the Early Years}

Science education is of great importance to many aspects of a child's development, and many researchers suggest science education should begin already during the early childhood period (Hadzigeorgiou 2002). Research studies in developmental and cognitive psychology indicate that environmental effects are important during the early years of development, and the lack of important stimuli may result in a child's development not reaching its full potential (Trundle 2010).

Implementing science learning in the early years can take advantage of children's disposition to learn about natural phenomena during their everyday activities. Science is all around us, therefore whether watching snails in an aquarium, blowing bubbles, using a flashlight to make shadows, or experimenting with objects to see what sinks or floats, a child is naturally curious and engaged in finding out about the world (Conezio and French 2002). In this way, already the youngest children actively engage with their environment to develop fundamental understandings of the phenomena they observe and experience. Children also acquire process skills essential to scientific interpretation, such as observing, classifying, sorting and others. These basic scientific concepts and science process skills begin to develop as early as infancy, with the sophistication of the child's competences developing with age (Trundle 2010).

Conezio and French (2002) believe that children are biologically prepared to learn about the world around them, just as they are biologically prepared to learn to walk and talk and interact with other people. Because they are ready to learn about their everyday world, they are highly engaged when opportunities to explore occur, creating strong and enduring mental representations of experiences through investigations of their everyday world. They readily acquire vocabulary to describe and share these mental repre- 
sentations and the concepts that naturally follow. Children then rely on the mental representations as the basis for further learning and for higher order intellectual skills such as problem solving, hypothesis testing, and generalizing across situations. Furthermore, in their study, Eshach and Fried (2005) summarize the reasons why even the smallest children should be exposed to science: (1) children naturally enjoy observing and thinking about nature; (2) exposing children to science develops positive attitudes towards science; (3) early exposure to scientific phenomena leads to better understanding of the scientific concepts studied later in life; (4) the use of scientifically informed language at an early age influences the subsequent development of scientific concepts; (5) children can understand scientific concepts and reason scientifically; (6) through experience science, children develop scientific thinking.

\section{The Importance of Preschool Science Education}

However, being only exposed to natural phenomena and observing the nature in the preschool period is not enough. To develop positive attitudes towards science, appropriate experience and engagement during development in combination with quality learning, are vital to help children understand the world, collect and organize information, and to apply and test their new ideas. For this, qualified adults, stimulating environments, and a good science education program are very important (Tu 2006), and results in all students gaining a solid foundation of core science knowledge and skills. This includes a coherent, well-designed curriculum, teachers who have the resources and skills to teach effectively; and communities and families that are committed to excellence (Mirzaie, Hamidi, and Anaraki 2009; Tu 2006).

Özbey and Alisinanoğlu (2008) believe that for science education, the primary school period is too late. Science education is necessary already in the preschool period, for the children to improve their creativity and learn about different perspectives. Moreover, science education in the preschool period forms the basis for the science education at primary school and that is why it is necessary early on. Children before the age of six need science education, so that they can learn about their living environment, natural phenomena, and generate original ideas (Mirzaie, Hamidi, and Anaraki 2009). Many researches in the last years have proven that preschool children have a much greater potential for learning and understanding science than previously thought - even in their earliest years. Both, the environment and the support of trained teachers, have a significant impact on the child's experience and subsequent lifelong learning of science (Garbett 2003; Worth 2010, 
Saçkes et al. 2011). Insufficient teaching of natural science in early childhood can lead to a negative attitude of pupils to science-related content that can persist until high school years and even longer (Mullis and Jenkins 1988). On the other hand, supporting children's natural thinking in the early years of childhood can lead children to transfer their own scientific way of thinking to other fields of science, and thus foster success and self-confidence in all areas of learning (Kuhn and Pearsall 2000).

\section{The Contribution of Early Science Education to Scientific Literacy}

What children of preschool age learn in terms of general science has shown to be a strong predictor of their future science achievement in school and later in life (Areljung 2018). Already early in life children develop a positive attitude towards science and lay the foundations for the further development of basic scientific concepts (Eshach and Fried 2005; Krnel 2008). The aims of science education are now commonly expressed in terms of developing 'scientific literacy', which is used as a term indicating the essential understanding that should be a part of everyone's education, rather than a detailed knowledge of facts and theories as required by scientists (Harlen and Qualter 2009). Science affects all our lives at every level. It governs the materials used to construct our homes, the way our food is grown and processed, the processes by which electricity is generated, the purpose of medicines and medical technology, and communication and transport technology. All fields children will be curious about at some time during development. A degree of scientific literacy is essential for everyone to enable making informed decisions about the scientific advances and developments which affect us all (Brunton and Thornton 2012). Therefore, the goal is to educate an individual who, in addition to the basic concepts, would be equipped with the abilities to understand abstract ideas and to discover nature and solve problems in a logical and scientific way (Krnel 2008). The PISA definition of scientific literacy is the capacity to use scientific knowledge, to identify questions and to draw evidence-based conclusions in order to understand and help make decisions about the natural world and the changes made to it through human activity (Organization for Economic Cooperation and Development 2003, 133).

\section{Learning Science Concepts}

Science is not just about exploration, but also about sharing and understanding accumulated knowledge. For children, the problem with science is to learn facts, which includes new words, or new contexts of words, because science, like many other activities, has its own technical vocabulary. A further 
difficulty is that some scientific explanations are counter-intuitive (Loxley et al. 2010; Allen 2014; Britten and Allen 2018). Children's everyday observations may lead them to hold firmly established ideas, which turn to be wrong in terms of science. For example, the Earth-centred model of the universe is an intuitive idea. When we watch the Sun rise in the east and set in the west, common sense tells us that it must be travelling around the Earth. The idea that this is an illusion caused by the spin of the Earth is counter-intuitive. Therefore, children sometimes find science too abstract and separate from their everyday understanding; the scientific accounts which they encounter do not map easily on to what children can see, feel and hear (Loxley et al. 2010).

Many different factors influence children's concepts of natural phenomena. In order to help children learn, and, even more importantly, understand science concepts, we must first comprehend the nature of their ideas about the world around them. Some authors suggest that children's concepts derive from their daily experiences, which are helpful and valuable in the child's daily life context (Driver, Guesne, and Tiberghien 1985; Duit and Treagust 1995; Trundle 2010). However, children's concepts are usually not scientific and these non-scientific ideas are called 'naïve concepts' or 'alternative concepts.' Duit and Treagust (1995) proposed six possible sources for alternative concepts: sensory experience, language experience, cultural background, peer groups, mass media, and even science instruction.

Children's interpretation of scientific concepts is influenced by the nature of their ideas. They tend to view the world and its phenomena from a selfcentred or human-centred, anthropocentric point of view, with which they often attribute human characteristics, such as feelings, will or purpose, to objects and phenomena (Piaget 1972; Bell 1993; Battelli and Dolenc-Orbanić 2006). For example, some children believe that the moon phases change because the moon gets tired. When the moon is not tired, we see a full moon. Then, as the moon tires, we see less of the moon (Trundle 2010). Of course, the natural explanation for this is that the lunar phases are created by changing relative positions of the Earth, the moon and the Sun, as the moon orbits the Earth.

Additionally, children usually focus on change rather than on static, steadystate situations, which make it difficult for them to recognize patterns on their own without the help of an adult or more knowledgeable peer. For example, when children observe mealworms over time they easily recognize how the mealworms' bodies change from larva to pupa and finally, to adult beetle. Still, they have difficulty noticing that the population count remains 
unchanged during the course of observation (Trundle 2010). In other words, the children would first notice that novel animals have populated the habitat, and only later that the earlier present animals have transformed. Children's concepts of natural processes are mostly undifferentiated. For example, children intuitively perceive the concept of living and non-living in a different way than adults or scientists do: plants are not living things to some young children because they do not move. However, the same children consider some non-living things, such as running water, fire and clouds, to be living things because they are not static (Allen 2014; Trundle 2010).

Children's ideas of scientific concepts are frequently extremely stable and can lead to misconceptions in science. Even after being formally taught in classrooms, children often do not change their ideas despite a teacher's attempts to challenge them by offering counter-evidence (Trundle 2010, 2014). As these misconceptions make a perfect sense to the child and can cause confusion with the alternate, scientifically correct ideas, presented later in class (Britten and Allen 2018), it is necessary that scientific concepts are always presented in a simple, but scientifically correct manner. These should be taught by a competent preschool teacher with suitable approaches, which will reduce the occurrence of misconceptions in preschool children.

\section{Effective Approaches towards Teaching Science to Preschool Children}

Science education in the last decades changed from a traditional, frontal way of teaching to contemporary instructional approaches as described in present-day science education literature (Trundle 2010). These latter draw heavily on the constructivist philosophy in which children act as active participants in the learning process and on the basis of their own experience, to construct knowledge. In this way, children's 'alternative concepts' are more likely to develop into correct science concepts later in their lives.

\section{Constructivist Philosophy}

Constructivism is the general name given to the dominant perspective on learning in education. It is grounded in the research and theories of Jean Piaget and Lev Vygotsky and the philosophy of John Dewey, and it is a natural extension of applied brain research. Many authors suggest that the nature and meaning of constructivism are open to interpretation and that there is not a single constructivist theory of learning (Gil-Pérez et al. 2002; Martin, Sexton, and Gerlovich 2014). Also Matthews (2000) states, that 'constructivism means different things to different researchers.' Some perspectives embrace the social nature of learning (Vygotsky), while radical constructivists place 
the importance on the individual's active, social participation in knowledge construction (Ernst von Glasersfeld). On the other hand, conservative constructivists (Piaget) use activity-based and problem-based learning experiences and teacher intervention to encourage conceptual constructions. Furthermore, the latter attempt to correct misconceptions in children by helping to construct understanding, based on concepts embraced by the scientific community (Gil-Pérez et al. 2002; Martin, Sexton, and Gerlovich 2014). Although there are many forms of constructivism, all of the instructional applications of constructivism view children as active agents in their personal construction of new knowledge. Furthermore, these instructional approaches aim to promote active learning through the use of hands-on activities with small groups and with sense-making discussions. A common expectation is that learners are more likely to construct an understanding of science content in this type of inquiry-based learning environment (Trundle 2010).

The theory of constructivism is based on the theory of Jean Piaget about mental equilibration and its interplay with assimilation and accommodation (Abruscato and DeRosa 2010; Martin, Sexton, and Gerlovich 2014):

- Equilibration. Learning is an active mental process, in which the child needs to construct knowledge by interacting with the environment. During that process, cognitive conflicts may arise between what is expected and what is observed (Driver, Guesne, and Tiberghien 1985). Each new interaction or conflict creates a dilemma in the child's mind how to maintain mental equilibrium (Martin, Sexton, and Gerlovich 2014). This principle is very important to the teachers of preschool children, because many children have naïve conceptions, which can persist up to the adult years. For a teacher, it is extremely difficult to help a child to construct new understanding if the child's naïve conceptions filter out new experiences (Abruscato and DeRosa 2010). With an attempt of restoring equilibrium, the learning child reaches a higher level of functional equilibration, and thus the formation of higher mental structures. However, equilibration is not a static mind-rest point, but a dynamic process (Martin, Sexton, and Gerlovich 2014).

- Assimilation is one way in which the mind can adapt to the learning challenge and restore equilibrium (Martin, Sexton, and Gerlovich 2014). Children try to reconcile new experiences and data with their present understanding so that the new data support and deepen, but do not change their fundamental mental model (Abruscato and DeRosa 2010).

- Accommodation. When no pre-existing mental structures are available 
to assimilate, children cannot reconcile new experience and data with their present understanding. Therefore, they need to change and adapt their mental model to logically explain the experience. This process of adaptation is called accommodation - the child's thinking is adapted to accommodate the dilemma (Abruscato and DeRosa 2010; Martin, Sexton, and Gerlovich 2014).

- Assimilation and accommodation are not mutually exclusive. They often complement each other in the learning process (Abruscato and DeRosa 2010).

A teacher, who accepts the constructivist philosophy, supports a different view of science, regards the roles of teacher and learner very differently, and selects and organizes teaching materials and the social learning environment with particular care (Martin, Sexton, and Gerlovich 2014; Trundle 2010). A constructivist perspective emphasizes the active role of the learner, in a physical, mental and social way. The constructivist teacher seeks ways to challenge and stimulate mental connection: offer order to enhance the active participation of learners in the learning process and encourage them to construct their own understanding of reality, which arises from their experience. In a simplified way, an ancient Chinese proverb encapsulates the intent of constructivism: 'I hear and I forget, I see and I remember, I do and I understand' (Martin, Sexton, and Gerlovich 2014).

\section{Inquiry-Based Learning}

An important didactic approach, based on the principles of constructivism, is the inquiry-based learning of which the beginners and supporters are many theorists, such as Kolb, Piaget, Dewey, Lewin, Neil and others (Marentič Požarnik 2000). The central idea of a guided inquiry approach is that individuals learn best by their own experiences and are active agents in the learning process. This strengthens children's sense of ownership in their work and enhances their motivation. With this approach, children usually work in a small group, which promotes their collaboration skills, mutual respect and tolerance and attitudes, inherent in the science education (Barell 2007; Ivanuš Grmek, Čagran, and Sadek 2009; Trundle 2010; Alveirinho, Bento, and Nunes 2017). Furthermore, the inquiry-based approach maintains children's curiosity and their permanent interest in knowledge, and further develops skills which are needed for solving problems independently (Petek 2012).

Meaningful science activities, which are relevant to children's daily lives, allow children to make connections between present and new knowledge. 
Sense-making discussions promote children's awareness of learning, concept development, and facilitate the restructuring of alternative ideas into scientific mental models. During the work of teachers with children their inquiry skills are developed, and the instructional strategies should move toward more open inquiry, where children are posing their own questions and designing their own investigations (Trundle 2010). One of the important components of inquiry-based learning is the experiment. Experiments in science through constructivist learning leads to the acquisition and development of a scientific literacy that involves skills, attitudes and values, which contribute to the formation of citizens, capable of dealing with everyday scientific aspects (Alveirinho, Bento, and Nunes 2017).

\section{The Reasons for the Lack of Science Teaching in Preschool Classrooms}

When preschool teachers are asked if they teach science, they might point to the plants on the shelf or the collection of stones and shells and indicate that science is taking place 'over there.' Other teachers see science as some kind of magic trick to perform on a Friday afternoon when children are already tired. They bring out the baking soda and vinegar to 'make a volcano.' While the children may be amazed and amused by this activity, it does not build accurate knowledge and does not represent real science. Real science begins with childhood curiosity, which leads to discovery and exploration with teachers' help and encouragement. It involves three major components: content, processes, and attitude. Young children prize information about the world around them, yet an emphasis on content is not enough. Young children, like scientists, need to practice the process skills of predicting, observing, classifying, hypothesizing, experimenting, and communicating. Like adult scientists, they need opportunities to reflect on their findings, how to they reach these, and how the findings compare to their previous ideas and the ideas of others. In this way, children are encouraged to develop the attitude of a scientist-that is, curiosity and the desire to challenge theories and share new ideas. Scientific exploration presents authentic opportunities to develop and use both receptive and expressive language skills (Conezio and French 2002).

As we already mentioned above, what children learn at the preschool age in terms of general science, has shown to be a strong predictor of their future science achievement in school (Morgan et al. 2016). Thus, it is worrying, that science teaching tends to be deprioritized in early childhood education, compared to teaching literacy, numeracy and arts (Areljung 2018). Several authors point out that many early childhood teachers are hesitant about introducing science in their preschool classrooms, often because of their own 
unpleasant science education experiences, or because of their insufficient content knowledge or alternative ideas about science topics (Conezio and French 2002; Kavalari, Kakana, and Christidou 2012; Broström 2015; Areljung 2018). Even Danish researches are showing that preschool teachers have a diffuse understanding of science education and they introduce children for science questions and phenomenon only in a limited range (Broström et al. 2014). A new Danish evaluation rapport shows that preschool children's study of 'nature and nature phenomenon' is the theme, which preschool teachers give less attention. Such a low priority is also seen in other countries (Broström 2015). American research reports that children's emergent skills on science learning are not taken into consideration in early childhood classroom (Tu 2006; Saçkes et al. 2011). Other studies show that teachers themselves do not have science competences and are not familiar with using science equipment, nor to follow children's science questions and wonder (Broström 2015). Also Kavalari, Kakana, and Christidou (2012) indicate that teachers show lack of confidence in approaching topics in science. Even more, teachers often doubt the benefits of science teaching (Eshach and Fried 2005).

Nevertheless, the reasons which lead to resisting pedagogical ideas for science teaching provide useful insights for designing professional development activities for preschool teachers (Areljung 2018). On the basis of their study and similar studies in the literature, Doğan and Simsar (2018) suggest some solutions, which could provide positive outcomes to preschool science education. They propose that teachers should increase their knowledge and skills by participating in various courses and seminars at regular intervals, thus following the innovations and changes related to science education. Further they suggest rearrangement of undergraduate preschool teacher education programs in terms of increasing the number and quality of courses of science education. In addition, it is suggested to decrease the number of children in the preschool classroom and include the parents into science activities when performed in the preschool classroom.

\section{Conclusions}

In their preschool years, children make the most significant progress in the development of cognitive, physical, linguistic, emotional, and social skills. In the last decades it is shown that science education is of great importance to the development of children, and many researchers suggest that science education should begin already during the early childhood period. The most important in early preschool science education is to choose appropri- 
ate instructional approaches and educate and employ competent preschool teachers. Under these circumstances, children's 'alternative conceptions' are more likely to develop into correct science concepts later in life and not stagnate in the form of undiscovered misconceptions.

\section{References}

Abruscato, J., and D. A. DeRosa. 2010. Teaching Children Science: A Discovery Approach. 7th ed. Boston, MA: Allyn \& Bacon.

Allen, M. 2014. Misconceptions in Primary Science. 2nd ed. Maidenhead: Open University Press.

Alveirinho, D., J. Bento, and M. Nunes. 2017. 'The Science Experiment and the Playful Learning: Window of Opportunity for Curricular Articulation in the Transition between Preschool Education and Primary Education.' In ICER/2017 Proceedings, edited by L. Gómez Chova, A. López Martínez, and I. Candel Torres, 8629-8635. Seville: IATED Academy.

Areljung, S. 2018. 'Why Do Teachers Adopt Or Resist a Pedagogical Idea for Teaching Science in Preschool?' International Journal of Early Years Education. https://doi.org/10.1080/09669760.2018.1481733

Barell, J. F. 2007. Problem-Based Learning: An Inquiry Approach. Thousand Oaks, CA: Corwin.

Batelli, C., and N. Dolenc-Orbanić. 2006. 'Zvita kot lisica, nesramna kot kukavica.' In Zgodnje učenje in poučevanje otrok, edited by V. Medved Udovič, M. Cotič, and D. Felda, 447-454. Koper: Annales.

Bell, B. 1993. Children's Science, Constructivism and Learning in Science. Burwood: Deakin University.

Britten, E., and M. Allen. 2018. Addressing Children Misconceptions through Talk: Unlocking Speaking and Listening; Developing Spoken Language in the Primary Classroom. 3rd ed. London: Routledge.

Broström, S. 2015. 'Science in Early Childhood Education.' Journal of Education and Human Development 2 (1): 107-124.

Broström, S., T. Frøkjær, I. Johansson, and A. Sandberg. 2014. 'Preschool Teacher's View on Learning in Preschool in Sweden and Denmark.' European Early Childhood Educational Research Journal 22 (5): 590-603.

Brunton, P., and L. Thornton. 2012. Science in the Early Years: Building Firm Foundations from Birth to Five. Los Angeles: Sage.

Conezio, K., and L. French. 2002. 'Science in the Preschool Classroom: Capitalizing on Children's Fascination with the Everyday World to Foster Language and Literacy Development.' Young Children 57 (5): 12-18.

Doğan, Y., and A. Simsar. 2018. 'Preschool Teachers' Views on Science Education, the Methods They Use, Science Activities, and the Problems They Face.' International Journal of Progressive Education 14 (5), 57-76.

Driver, R., E. Guesne, and A. Tiberghien. 1985. 'Some Features of Children's Ideas 
and Their Implications for Teaching.' In Children's Ideas in Science, edited by R. Driver, E. Guesne, and A. Tiberghien, 193-201. Philadelphia: Open University Press.

Duit, R., and D. F. Treagust. 1995. 'Students' Conceptions and Constructivist Teaching Approaches.' In Improving Science Education, edited by B. J. Fraser and H. J. Walberg, 46-69. Chicago: The University of Chicago Press.

Eshach, H., and M. N. Fried. 2005. 'Should Science be Taught in Early Childhood?' Journal of Science Education and Technology 14 (3): 315-336.

Garbett, D. 2003. 'Science Education in Early childhood Teacher Education: Putting forward a Case to Enhance Student Teachers' Confidence and Competence.' Research in Science Education 33:467-481.

Gil-Pérez, D., J. Guisasola, A. Moreno, A. Cachapuz, A. M. Pessoa De Carvalho, J. Martínez Torregrosa, J. Salinas et al. 2002. 'Defending Constructivism in Science Education.' Science \& Education 11:557-571.

Hadzigeorgiou, Y. 2002. 'A Study of the Development of the Concept of Mechanical Stability in Preschool Children.' Research in Science Education 32 (3): 373-391.

Harlen, W., and A. Qualter. 2009. The Teaching of Science in Primary Schools. 5th ed. London: Routledge.

Ivanuš Grmek, M., B. Čagran, and L. Sadek. 2009. Didaktični pristopi pri poučevanju predmeta Spoznavanje okolja $v$ tretjem razredu osnovne šole. Znanstvena poročila Pedagoškega inštituta. Ljubljana: Pedagoški inštitut.

Kavalari, P., D. M. Kakana, and V. Christidou. 2012. 'Contemporary Teaching Methods and Science Content Knowledge in Preschool Education: Searching for Connections.' Procedia: Social and Behavioural Sciences 4:3649-3654.

Krnel, D. 2008. 'Narava.' In Otrok v vrtcu: priročnik h kurikulumu za vrtce, edited by L. Marjanovič Umek, 157-175. Maribor: Obzorja.

Kuhn, D., and S. Pearsall, S. 2000. 'Developmental Origins of Scientific Thinking.' Journal of Cognition and Development 1:113-129.

Loxley, P., L. Dawes, L. Nicholls, and B. Dore. 2010. Teaching Primary Science: Promoting Enjoyment and Developing Understanding. Harlow: Pearson Education.

Marentič Požarnik, B. 2000. Psihologija učenja in pouka. Ljubljana: DZS.

Martin, R., C. Sexton, and J. Gerlovich. 2014. Teaching Science for All Children. Harlow: Pearson Education.

Matthews, M. R. 2000. 'Editorial of the Monographic Issue on Constructivism, Epistemology and the Learning of Science.' Science and Education 9:491505.

Mirzaie, A. R., F. Hamidi, and A. Anaraki. 2009: 'A Study on the Effect of Science Activities on Fostering Creativity in Preschool Children.' Journal of Turkish Science Education 6 (3): 81-90.

Morgan, P. L., G. Farkas, M. M. Hillemeier, and S. Maczuga. 2016. 'Science Achieve- 
ment Gaps Begin Very Early, Persist, and Are Largely Explained by Modifiable Factors.' Educational Researcher 45 (1): 18-35.

Mullis, I. V. S., and L. B. Jenkins. 1988. 'The Science Report Card.' Report No. 175-01, Educational Testing Service, Princeton, NJ.

Organization for Economic Cooperation and Development. 2003. The PISA 2003 Assessment Framework. Paris: Organization for Economic Cooperation and Development.

Özbey, S., and F. Alisinanoğlu. 2008: 'Identifying the General Ideas, Attitudes and Expectations Pertaining to Science Activities of the Teachers Employed in Preschool Education.' Journal of Turkish Science Education 5 (2): 82-94.

Petek, D. 2012. 'Zgodnje učenje in poučevanje naravoslovja z raziskovalnim pristopom.' Revija za elementarno izobraževanje 5 (4): 101-114.

Piaget, J. 1972. Child's Conceptions of the World. Lanham, MD: Littlefield Adams.

Saçkes, M., K. C. Trundle, R. Bell, and A. A. O'Connol. 2011. 'The Influence of Early Science Experience in Kindergarten on Children's Immediate and Later Science Achievement: Evidence from the Early Childhood Longitudinal Study.' Journal of Research in Science Teaching 48 (2): 217-235.

Trundle, K. C. 2010: 'Teaching Science During the Early Childhood Years.' http:// ngl.cengage.com/assets/downloads/ngsci_proo000000028/am_trundle _teach_sci_early_child_scl22-0429a.pdf

Trundle, K. C. 2014. 'Teaching Young Children Science.' In Contemporary Perspectives and Research on Early Childhood Education, edited by M. Yasar, O. Ozgun, and J. Galbraith, 126-134. Newcastle: Cambridge Scholars Publishing.

Tu, T. 2006. 'Preschool Science Environment: What Is Available in a Preschool Classroom?' Early Childhood Education Journal 33:245-251.

Worth, K. 2010. 'Science in Early Childhood Classrooms: Content and Process.' http://ecrp.illinois.edu/beyond/seed/worth.html

\section{Pomen konstruktivističnega pristopa poučevanja zgodnjega naravoslovja v vrtcu}

Učenje naravoslovja je zelo pomembno za številne vidike otrokovega razvoja, zato mnogi znanstveniki svetujejo, da bi otroci z njim pričeli že $v$ zgodnjem predšolskem obdobju. Danes je poučevanje zgodnjega naravoslovja v vrtcu zasnovano pretežno na načelu konstruktivizma, po katerem otroci v učnem procesu delujejo kot aktivni udeleženci in svoje znanje gradijo na podlagi izkušenj. To jim omogoča pridobivanje znanstvenih spoznanj in razvoj sposobnosti razmišljanja ter reševanja problemov na logičen način. Pri tem igra bistveno vlogo kompetenten vzgojitelj, ki otrokom pomaga razvijati pozitiven odnos do naravoslovja ter postavlja temelje za nadaljnji razvoj naravoslovnih konceptov in s tem osnovo nadaljnjemu učenju naravoslovja v šoli. Vendar pa številne študije kažejo, da je poučevanje zgodnjega naravoslovja po vsem 
svetu v primerjavi s poučevanjem matematike, jezika, književnosti in umetnosti zapostavljeno, pretežno zaradi nezadostnega naravoslovnega znanja vzgojiteljev. Znanstveniki zato predlagajo rešitve, ki bi k pogostejšemu poučevanju zgodnjega naravoslovja v vrtcu pripomogle s pomočjo dodatnih izobraževanj vzgojiteljev.

Ključne besede: poučevanje zgodnjega naravoslovja, konstruktivizem, kompetentni vzgojitelji, naravoslovni koncepti, naravoslovna pismenost 